\title{
ANALISIS TINGKAT KECERDASAN SOSIAL SISWA DALAM PEMBELAJARAN IPS KELAS IV SDN PETIR 4 KOTA TANGERANG
}

\author{
${ }^{1}$ Nadhia Ummah, ${ }^{2}$ Rahmawati Eka Saputri, ${ }^{3}$ Sa'odah \\ ${ }^{1,2,3}$ Universitas Muhammadiyah Tangerang
}

Email : Nadhiaummah@gmail.com, friskarosendaalista@gmail.com, saodah.umt@gmail.com

\begin{abstract}
Abstrak
Penelitian ini bertujuan untuk mengetahi bagaimana tingkat kecerdasan sosial dalam pembelajaran IPS siswa kelas IV SDN Petir 4 Kota Tangerang. Metode yang digunakan dalam penelitian ini menggunakan metode deskriptif kualitatif, dengan subyek penelitian siswa kelas IV yang berjumlah 25 siswa. instrumen yang digunakan dalam penelitian ini adalah daftar pernyataan berupa angket yang kemudian diberikan kepada objek penelitian, yaitu siswa kelas IV SDN Petir 4 Kota Tangerang. Selain angket, peneliti juga menggunakan instrumen daftar pertanyaan wawancara, observasi dan dokumentasi. Wawancara digunakan untuk mengajukan pertanyaan kepada guru untuk mendapatkan informasi yang akurat mengenai tingkat kecerdasan sosial siswa dalam pembelajaran IPS. Observasi digunakan untuk mengamati bagaimana tingkat kecerdasan sosial siswa dalam kegiatan pembelajaran dikelas dan penelitian ini dapat diperkuat dengan dokumentasi. Data hasil pengamatan kemudian dianalisis dengan perhitungan perolehan rata-rata persentase tingkat kecerdasan sosial siswa dalam pembelajaran IPS. Berdasarkan hasil analisis, dapat disimpulkan bahwa minat membaca buku teks pelajaran bahasa Indonesia siswa kelas IV SDN Petir 4 Kota Tangerang dikategorikan Tinggi.
\end{abstract}

Kata Kunci : Tingkat kecerdasan sosial, pembelajaran IPS

\section{Abstract}

This study aims to determine how the level of social intelligence in social studies learning for fourth grade students of SDN Petir 4 Kota Tangerang. The method used in this study used a qualitative descriptive method, with the research subjects of grade IV students totaling 25 students. The instrument used in this study was a list of statements in the form of a questionnaire which was then given to the research object, namely the fourth grade students of SDN Petir 4 Kota Tangerang. Apart from the questionnaire, the researcher also used the questionnaire, interview, observation and documentation instruments. Interviews are used to ask questions to the teacher to get accurate information about the level of social intelligence of students in social studies learning. Observation is used to observe how the level of students' social intelligence in classroom learning activities and this research can be strengthened by documentation. The data from the observations were then analyzed by calculating the average percentage acquisition of students' social intelligence levels in social studies learning. Based on the results of the analysis, it can be concluded that the interest in reading Indonesian language textbooks for grade IV SDN Petir 4 Kota Tangerang is in the high category.

Keywords: Level of social intelligence, social studies learning 


\section{PENDAHULUAN}

Dunia pendidikan memegang peranan penting bagi kelangsungan hidup suatu bangsa, melalui pendidikan generasi penerus bangsa yang berkualitas akan lahir dan menjadi pemimpin yang bertanggung jawab. Menurut Undang-Undang Nomor 20 tahun 2003 tentang Sistem Pendidikan Nasional pasal 3 menjelaskan : Pada Bab 1 pasal 1 ayat 1 tentang sistem pendidikan nasional dinyatakan bahwa "pendidikan adalah usaha sadar dan terencana untuk mewujudkan suasana belajar dan proses pembelajaran agar peserta didik secara aktif mengembangkan potensi dirinya untuk memiliki kekuatan spiritual keagamaan, pengendalian diri, kepribadian, kecerdasan, akhlak mulia, serta keterampilan yang diperlukan dirinya, masyarakat, bangsa dan negara“" (Sisdiknas, 2003).

Pendidikan sebagai salah satu proses perubahan pada pembentukan sikap, kepribadian dan keterampilan manusia untuk menghadapi masa depan. Dalam proses pertumbuhan dan perkembangan itu dipengaruhi oleh berbagai faktor-faktor yang menyangkut perilaku manusia, kemampuan dan kemauan belajar sehingga pada akhirnya proses tersebut mendorong pertumbuhan dan perkembangan kearah suatu tujuan yang dicita-citakan dan diharapkan perubahan tersebut membawa dampak positif.

Menurut Thorndike Kecerdasan sosial merupakan kemampuan untuk memahami dan mengelola hubungan manusia. (Sunar, 2010, h.21). Kecerdasan sosial berarti orang yang mampu membuat orang-orang berada di sekitarnya merasa nyaman dan santai dengan keberadaan dirinya. Adapun teori kecerdasan sosial pertama kali dicetuskan oleh William Gardner di tahun 1990an dan kemudian disempurnakan lagi oleh Daniel Goleman melalui bukunya yang berjudul "Social Intelligence" di tahun 2007 serta Karl Albrecht melalui bukunya yaitu "Social Intelligence Theory" di tahun 2006. menjelaskan bahwa kecerdasan sosial yaitu kecerdasan yang menunjukkan kemampuan seseorang untuk peka dalam memahami dan berinteraksi dengan orang lain, sehingga individu tersebut akan mudah bersosialisai dengan lingkungan di sekelilingnya. (Soejanto, 2015, h.19). Gardner secara spesifik menjelaskan bahwa kecerdasan sosial merupakan aspek kualitas individu dalam ranah kognitif dan tingkah laku. sikap (attitude) adalah istilah ya ng mencerminkan rasa senang, tidak senang, atau biasa-biasa saja (netral) dari seseorang terhadap sesuatu (Sarwono, 2010), Tingkat kecerdasan sosial dilakukan dengan harapan akan menghasilkan suatu perubahan 
sikap kesadaran diri yang lebih baik terhadap anak, dengan tujuan agar melakukan perbaikan atau penyempurnaan sikap, sehingga pada masa yang akan datang siswa dapat menerapkan sikap yang dapat atau layak diterapkan di lingkungan masyarakat maupun lingkungan sekolah. Menurut Aldily Kecerdasan sosial merupakan kemampuan untuk beradaptasi dan diterima oleh lingkungan sekitar, sedangkan kecerdasan emosional merupakan kemampuan seseorang dalam mengontrol diri terhadap segala hal yang negative (Aldily, 2017).

Pada ketentuan standar nasional pendidikan yang dapat mencangkup tentang mengembangkan potensi dirinya untuk memiliki kekuatan spiritual keagamaan, pengendalian diri, kepribadian, kecerdasan, akhlak mulia, serta keterampilan yang diperlukan dirinya, standar isi yaitu mencangkup sikap respon siswa dalam proses pembelajaran bagaimana cara siswa merespon di lingkungan sekitarnya. Dalam proses pembelajaran sikap diperlukan untuk kemampuan siswa dalam menanggapi respon seseorang yang sedang berinteraksi dengannya. Karena ketika siswa berinteraksi dengan temannya atau orang lain dan tidak terjadi respon yang baik atau siswa mengacuhkannya, maka tingkat kecerdasan siswa itu dikatakan respon pasif. Kriteria tersebut membutuhkan pemikiran yang sistematis, logis, dan kritis yang dapat dikembangkan melalui peningkatan mutu pendidikan kemudian dikembangkan melalui pembelajaran Ilmu Pengetahuan Sosial (IPS). Kata atau istilah pembelajaran dan penggunaannya masih tergolong baru, yang mulai popular semenjak lahirnya Undang-Undang Sistem Pendidikan Nasional No. 20 Tahun 2003. Menurut undang-undang ini, pembelajaran diartikan sebagai proses interaksi peserta didik dengan pendidik dan sumber belajar pada suatu lingkungan belajar. Menurut pengertian ini, pembelajaran merupakan bantuan yang diberikan pendidik agar terjadi proses pemerolehan ilmu dan pengetahuan, penguasaan, kemahiran, dan tabiat, serta pembentukan sikap dan keyakinan pada peserta didik (Susanto, 2013, h.19). Dengan karta lain, pembelajaran adalah proses untuk membantu peserta didik agar dapat belajar dengan baik. Namun dalam implementasinya, sering kali kata pembelajaran ini diidentikan dengan kata mengajar.

Ilmu Pengetahuan Sosial (IPS) merupakan bidang studi yang diajarkan pada tingkat pendidikan sekolah dasar. Selain itu dalam pemberian materi harus di perhatikan, hal ini untuk menghindari kesalahan atau kekurangan penerimaan konsep pada anak dengan benar dan memperhatikam psikologis anak yang di mulai dari perilaku, sikap dan juga cara anak berinteraksi dengan teman sebayanya, ukuran itulah yang di namakan karakteristik. 
Ilmu Pengetahuan Sosial (IPS) merupakan salah satu komponen dari berbagai mata pelajaran yang mempunyai peran penting dalam dunia pendidikan. Pembelajaran IPS di SD merupakan mata pelajaran yang dimaksud agar siswa mempunyai pengetahuan, gagasan dan sikap sosial yang terorganisasi tentang lingkungan sekitar, yang di peroleh dari pengalaman melalui interaksi, bersosialisasi dan sikap keyakinan social (Sardjijo, 2017). Jadi pembelajaran IPS salah satu mata pelajaran yang harus diajarkan di sekolah dasar. Namun sampai saat ini masih banyak siswa yang merasa IPS sebagai mata pelajaran yang membosankan atau tidak menyenangkan, bahkan salah satu mata pelajaran yang tidak dihiraukan oleh siswa. Hal ini dikarenakan masih banyak siswa yang mengalami kesulitankesulitan dalam mengerjakan soal IPS. Selanjutnya, guru yang mengajar di SDN Petir 4 Kota Tangerang, menginformasikan bahwa mereka sudah melakukan uji coba dalam materi IPS yang mencangkup tentang kecerdasan sosial atau tentang sikap respon siswa terhadap lingkungan sekolah, dari analisis tersebut dapat dijelaskan bahwa sikap siswa dengan cara merespon itu masih dikatakan pasif walauppun masih ada siswa yang bersikap positif. Ini dapat ditunjukan dengan banyaknya siswa yang belum memahami dan memanfaatkan kecerdasan sosial dalam proses pembelajaran IPS.

Salah satu kesalahan yang paling utama yaitu sikap siswa dalam merespon pada saat jam pembelajaran tidak baik, hal itu yang dapat menyebabkan kurangnya pemahaman dan konsentrasi belajar pada siswa, dan ada pula sebagian besar siswa dalam proses pembelajaran IPS sering berbuat kejahilan dengan temanya bahkan ada yang bertengkar dengan teman sebangkunya. Ketika guru memberikan umpan pertanyaan beberapa siswa yang terlihat antusias ingin menjawab pertanyaan dari guru. Lalu ketika guru sudah menunjuk siswa untuk menjawab pertanyaan, siswa tersebut malah menolak dan menunjuk temanya untuk menjawab sikap inilah yang menunjukan bahwa siswa tidak memiliki kecerdasan sosial. Sehingga hal ini dapat dikatakan tingkat kecerdasan sosial siswa di SDN Petir 4 kelas IV dengan cara siswa merespon saat proses pembelajaran terutama di pembelajaran IPS walaupun tidak semua siswa masih ada siswa yang bersikap cukup baik pada saat proses pembelajaranl, maka ketidak mampuan siswa dalam menghubungkan sikap terhadap konsentrasi kurang tepat. Namun, kesalahan yang di lakukan siswa bukanlah hal yang negatif karena guru dapat mengambil manfaat dari kesalahan-kesalahan tersebut untuk memperbaiki pengajaran yang sedang dan akan berlangsung. Karena itu penting bagi guru untuk mengetahui jenis kesalahan yang sering muncul seperti kesalahan dalam tingkat kecerdasan sosial dan mencari tahu faktor 
Indonesian Journal of Elementary Education

Vol. 1, No.2, Juli 2021

E-ISSN: $2722-6689$

http://jurnal.umt.ac.id/index.php/IJOEE

terjadinya kesalahan tersebut. Dari permasalahan tersebut, penulis perlu melakukan penelitian yang mendalam guna mendapatkan jawaban atas masalah-masalah tersebutdengan judul " Analisis Tingkat Kecerdasan Sosial Siswa Dalam Pembelajaran IPS Kelas IV SDN Petir 4 Kota Tangerang.

\section{METODE PENELITIAN}

Penelitian ini menggunakan metode kualitatif dengan metode penelitian deskriptif kualitatif dan dengan menggunakan pendekatan naturalistik. Sebagaimana yang dikemukakan Moleong (2016, h.6) menyebutkan bahwa: "Penelitian kualitatif adalah penelitian yang bermaksud untuk memahami fenomena tentang apa yang dialami oleh subjek penelitian misalnya perilaku, persepsi, motivasi, tindakan, dll. Metode kualitatif adalah metode penelitian yang berlandaskan pada filasafat post positivisme, digunakan untuk meneliti pada kondisi obyek yang alamiah, (Sugiyono, 2016) (sebagai lawannya adalah eksperimen) dimana peneliti adalah sebagai instrumen kunci, pengambilan sampel sumber data dilakukan secara purposive dan Snowbaal, tehnik pengumpulan dengan trianggulasi (gabungan), analisis data bersifat Induktif atau kualitatif, dan hasil penelitian kualitatif lebih menekankan makna dari pada generalisasi.

\section{HASIL DAN PEMBAHASAN}

Berdasarkan hasil pengamatan yang telah dilakukan maka secara garis besar dapat ditarik kesimpulan bahwa tingkat kecerdasan sosial siswa dalam pembelajaran IPS dapat dikategorikan cukup tinggi. Hasil tabel 4.1 dengan butir pernyataan

Tabel Kriteria Angket Tingkat Kecerdasan Sosial

\begin{tabular}{|c|c|}
\hline kategori & Jumlah skor \\
\hline Tinggi (121- 160) & 21 \\
\hline Sedang (81-120) & 4 \\
\hline Rendah (40-80) & 0 \\
\hline
\end{tabular}


Berdasarkan analisis data tersebut bahwa yang termasuk kriteria tinggi ada 21 siswa (84\%), yang termasuk kategori sedang ada 4 siswa (16\%) dan yang termasuk kategori rendah ada 0 siswa (0\%). Berdasarkan Kesimpulan yang dapat diambil dari hasil pengumpulan data mengenai tingkat kecerdasan sosial siswa kelas IV dalam pembelajaran IPS yaitu sikapnya cukup baik walaupun memang belum seluruh siswa yang bersikap atau respon positif terhadap pembelajaran IPS. Tugas guru disini yaitu memotivasi siswa agar tergugah dalam diri siswa untuk meningkatkan kecerdasan sosial siswa. Oleh karena itu dapat disimpulkan bahwa tingkat kecerdasan sosial siswa di SDN Petir 4 Kota Tangerang termasuk kategori tinggi.

Hasil penelitian juga diperoleh dari hasil angket yang diberikan kepada siswa berupa indikator kecerdasan sosial siswa dalam pembelajaran IPS. Adapun butir yang ada diukur dalam hasil berikut, yaitu Butir Ke-1 : Meskipun berbeda pendapat dengan orang lain saya tetap menghormatinya. Berdasarkan hasil angket diketahui bahwa $60 \%$ siswa sangat menghormati orang lain walaupun diantara mereka berbeda pendapat, $40 \%$ menghormati orang lain walaupun berbeda pendapat. hal tersebut dapat disimpulkan bahwa sebagian besar siswa sangat setuju jika tetap menghormati orang lain walaupun berbeda pendapat dalam proses pembelajaran. Butir Ke-2 : saya menyadari bagaimana perasaan guru jika sedang menjelaskan tidak didengarkan. Berdasarkan hasil angket diketahui bahwa 44\% siswa sangat menyadari bagaimana perasaan guru pada saat menjelaskan tidak mendengarkannya, $48 \%$ siswa menyetujui menyadari persaan guru pada saat menjelaskan tidak didengarkan, $8 \%$ siswa tidak setuju bahwa mereka dapat menyadari perasaan guru. Dengan demikian dapat disimpulkan bahwa sebagian besar siswa sangat menyukai guru bahasa Indonesia, hal tersebut menunjukkan bahwa sebagian siswa menyetujui dengan sikap menyadari perasaan guru pada saat mengajar lalu siswa tidak mendengarkannya. Butir yang ke-3 : Saya terharu bila ada teman yang menangis. Berdasarkan hasil angket menunjukkan jika ada teman yang menangis ia terharu atau tidak, terdapat $20 \%$ siswa sangat terharu bila ada teman yang menangis, $72 \%$ menyetujui bila ada teman menangis ia terharu, $8 \%$ siswa merasa tidak setuju jika ada teman menangis ia harus terharu. Dengan demikian bahwa sikap respon terhadap temannya sebagian besar siswa menyetuji terharu dengan temannya yang menangis.

Butir yang ke-4: Apabila ada teman yang jahil maka saya tidak akan membalasnya. Berdasarkan angket dapat diketahui bahwa Jika ada teman yang jahil maka saya tidak akan membalasnya, terdapat $36 \%$ siswa menyatakan sangat setuju, $64 \%$ siswa menyatakan setuju, 
dan $12 \%$ siswa menyatakan tidak setuju. Dengan demikian siswa kelas IV SDN Petir 4 tidak akan membalas jika ada teman yang jahil, hal ini dibuktikan dengan pilihan siswa yang setuju dengan pendapat mereka tidak akan membalas perbuatan temannya yang jahil. Butir ke-5: jika bertermu Bapak/Ibu guru saya selalu nyapa walaupun di luar sekolah. Berdasarkan hasil angket diketahui bahwa, terdapat $64 \%$ siswa menyatakan jika bertemu guru saya selalu nyapa walaupun di luar sekolah, 36\% siswa menyatakan setuju. Dengan demikian dapat disimpulkan bahwa sebagian siswa sangat setuju dengan pendapat mereka tentang sikap mereka jika bertemu dengan bapak/ibu guru di luar sekolah. Hal tersebut bisa di tunjukan pada tabel diatas terdapat $64 \%$ siswa yang sangat setuju. Butir ke-6: Saya menyadari sikap orang lain terhadap sikap buruk yang dilakukan. Berdasarkan hasil angket dapat diketahui bahwa siswa menyadari sikap orang lain terhadap sikap buruk yang di lakukan, terdapat $20 \%$ siswa menyatakan sangat setuju, $64 \%$ siswa menyatakan setuju, $12 \%$ siswa menyatakan tidak setuju, 4\% siswa menyatakan sangat tidak setuju. Dengan demikian dapat disimpulkan bahwa siswa menyadari sikap orang lain terhadap sikap buruk yang di lakukan sebagian siswa menyetujui karena jumlah skor setuju sangat tinggi di bandingkan dengan yang tidak setuju dan sangat tidak setuju.

Butir ke-7: Saya merasa sedih jika ada teman yang tinggal kelas. Berdasarkan angket dapat diketahui bahwa siswa kelas IV merasa sedih jika ada teman yang tinggal kelas, terdapat $36 \%$ siswa menyatakan sangat setuju, 52\% menyatakan setuju, dan $12 \%$ siswa menyatakan tidak setuju. Dengan demikian dapat disimpulkan bahwa benar siswa kelas IV merasa sedih jika ada temannya yang tinggal kelas karena dapat dilihat dari jumlah siswa yang menyatakan setuju lebih besar dibandingkan dengan jumlah siswa yang menyatakan tidak setuju. Hal tersebut menunjukkan bahwa sikap siswa terhadap temannya berespon positif. Butir ke-8: Meski Saya cerdas harus tetap giat belajar. Berdasarkan angket diketahui bahwa meskipun sudah cerdas harus tetap giat belajar $72 \%$ siswa menyatakan sangat setuju dan $28 \%$ siswa menyatakan setuju. Dengan demikian dapat disimpulkan bahwa semangat belajar mereka sangat besar. Hal ini berkaitan dengan kecerdasan siswa yang berasal dari dalam dirinya. Butir ke-9: Jika ada teman yang tidak bersedia berteman maka saya tetap menemaninya atau menganggap sebagai teman. Berdasarkan angket dapat diketahui bahwa sebanyak $28 \%$ siswa menyatakan sangat setuju dengan pernyataan jika ada teman yang tidak bersedia berteman maka saya tetap menemani atau menganggap sebagai teman dan $72 \%$ siswa menyatakan setuju terhadap pernyataan tersebut. Dengan demikian 
dapat disimpulkan bahwa jika tidak ada yang bersedia menemaninya maka akan tetap menganggapnya sebagai teman.

Butir ke-10: Walaupun dalam suasana menegangkan saya tetap berkonsentrasi dalam berfikir. Berdasarkan angket dapat diketahui bahwa walaupun dalam suasana menegangkan saya tetap berkonsentrasi dalam berfikir sebanyak $28 \%$ menyatakan sangat setuju dan $72 \%$ siswa menyatakan setuju. Dengan demikian dapat disimpulkan bahwa dalam suasana menegangkan mereka tetap berkonsentrasi dalam berfikir, hal ini dibuktikan dengan pilihan siswa yang yang menyatakan setuju. Butir ke-11: Jika guru menghukum karena kesalahan maka saya harus menerimanya. Berdasarkan angket dapat diketahui bahwa guru menghukum karena kesalahan maka mereka harus menerimanya, terdapat $28 \%$ siswa menyatakan sangat setuju dan $72 \%$ siswa menyatakan setuju. Dengan demikian dapat disimpulkan bahwa guru menghukum karena kesalahan siswa maka siswa harus menerimanya pernyataan ini bisa dilihat dengan pernyataan siswa memilih setuju apabila mereka dihukum karena kesalahan mereka sendiri. Butir ked-12: Saya mudah bergaul dengan teman walaupun tidak sekelas. Berdasarkan angket dapat diketahui ada sebanyak 7\% siswa menyatakan sangat setuju, 64\% sisw menyatakan setuju, dan $8 \%$ siswa menyatakan tidak setuju. Dengan demikian dapat disimpulkan bahwa siswa kelas IV SDN Petir 4 mudah bergaul walaupun tidak hanya dengan teman sekelasnya. Hal tersebut menunjukkan bahwa siswa yang memilih setuju lebih banyak dibandingkan denga tidak setuju.

Butir ke-13: Saya akan berusaha masuk 10 besar walaupun sulit. Berdasarkan angket dapat diketahui bahwa siswa akan berusaha masuk 10 besar walaupun sulit ada sebanyak $56 \%$ siswa menyatakan sangat setuju dan $44 \%$ siswa menyatakan setuju. Dengan demikian dapat disimpulkam bahwa siswa berusaha agar mereka dapat peringkat 10 besar walaupun itu sulit untuk siswa kelas IV SDN Petir 4. Butir ke-14: Saya menyadari kekurangan dalam diri di sekolah maka mengimbanginya dengan giat belajar. Berdasarkan angket dapat diketahui bahwa siswa menyadari kekurangan dalam diri di sekolah maka mengimbanginya dengan giat belajar ada sebagian besar siswa menjawab 52\% menyatakan sangat setuju dan $48 \%$ siswa menyatakan setuju. Dengan demikian dapat disimpulkan bahwa respon positif siswa cukup baik terhadap dirinya sendiri. Hal ini menunjukkan bahwa antusias siswa terhadap dirinya dapat di tunjukan tabel di atas $52 \%$ siswa sangat setuju. 
Butir ke-15: Saya menyadari hal-hal yang dapat menyebabkan malas belajar IPS. Dari angket dapat diketahui bahwa ada sebanyak 24\% siswa menyatakan sangat setuju, 12\% siswa menyatakan setuju, dan $28 \%$ siswa menyatakan tidak setuju. Dengan demikian dapat disimpulkan bahwa hal yang dapat menyebabkan siswa malas belajar pembelajaran IPS cukup tinggi karena jawaban dari pernyataan di tabel atas sangat bervariasi dan selisihnya sedikit. Hal ini menunjukkan bahwa siswa tahu hal apa saja yang membuat mereka malas belajar. Butir ke-16: Jika ada ulangan IPS maka saya semangat belajar. Berdasarkan angket dapat diketahui bahwa ada sebanyak 44\% siswa menyatakan sangat setuju dan $56 \%$ siswa menyatakan setuju. Dengan demikian dapat disimpulkan bahwa jika ada ulangan IPS siwa semangat belajar. Hal ini menunjukkan bahwa sebagian besar siswa memilih setuju dan dapat terbukti pada tabel di atas. Butir ke- 17: Jika ada teman yang tidak mengerti dengan pelajaran IPS saya mencoba menjelaskan kembali. Berdasarkan angket dapat diketahui sebanyak $28 \%$ siswa menyatakan sangat setuju dengan pernyataan jika ada teman yang tidak mengerti dengan pelajaran IPS saya mencoba menjelaskan kembali, sebanyak $72 \%$ siswa menyatakan setuju. Dengan demikian dapat disimpulkan bahwa sebagian besar siswa kelas IV jika ada temannya yang tidak mengerti dengan pelajaran IPS saya mencoba untuk menjelaskan kembali. Hal ini menunjukkan bahwa siswa mempunyai respon positif terhadap temannya.

Butir ke-18: Saya senang jika hidup rukun dan bersosialisasi. Dari angket diketahui bahwa sebanyak $60 \%$ siswa menyatakan sangat setuju dengan pernyataan saya senang jika hidup rukun dan bersosialisasi, $9 \%$ siswa menyatakan setuju dan $4 \%$ siswa menyatakan tidak setuju. Dengan demikian dapat disimpulkan bahwa sebagian besar siswa senang jika hidup rukun dan bersosialisasi. Hal ini menunjukkan bahwa sebagian besar siswa setuju dengan hidup rukun dan bersosialisasi walaupun masih ada siswa yang tidak setuju dengan pernyatatan tersebut. Butir ke- 19: Saya rajin mengikuti kegiatan bakti sosial tanpa mengharapkan imbalan dari orang tua, guru, teman maupun masyarakat. Dari tabel di atas dapat diketahui bahwa siswa rajin mengikuti kegiatan bakti sosial tanpa mengharapkan imbalan ada sebanyak $60 \%$ menyatakan sangat setuju dan $40 \%$ siswa menyatakan setuju. Dengan demikian dapat disimpulkan bahwa respon siswa ketika mengikuti kegiatan bakti sosial sangat positif dan siswapun tidak mengharapkan imbalannya dari siapapun. Butir ke20: Jika ada kuis pelajaran IPS saya berusaha untuk bisa jawab. Dari angket dapat diketahui bahwa jika ada kuis pelajaran IPS saya berusaha untuk bisa menjawab ada sebanyak 
$24 \%$ siswa menyatakan sangat setuju dan $76 \%$ siswa menyatakan setuju. Dengan demikian dapat disimpulkan bahwa pada saat ada kuis pelajaran IPS siswa berusaha untuk bisa menjawab. Hal ini menunjukkan bahwa sebagian besar siswa selalu berusaha untuk menjadi yang terbaik di kelasnya.

Butir ke-21: Saya tidak mudah bergaul dengan teman sekelas. Dari angket dapat diketahui bahwa siswa tidak mudah bergaul dengan teman sekelas ada sebanyak $20 \%$ siswa menyatakan sangat tidak setuju, $72 \%$ siswa menyatakan tidak setuju dan ada juga $8 \%$ siswa menyatakan setuju. Dengan demikian dapat disimpulkan bahwa siswa kelas IV mudah bergaul dengan teman. Hal ini menunjukkan di atas sebagian besar siswa memilih tidak setuju dengan angket pernyataan negatif. Butir ke-22: Saat guru menunjuk untuk maju kedepan kelas saya tidak berani. Dari angket dapat diketahui bahwa pada saat guru menunjuk untuk maju kedepan kelas saya tidak berani ada sebanyak 6\% siswa menyatakan sangat tidak setuju dan 19\% siswa menyatakan tidak setuju. Dengan demikian dapat disimpulkan bahwa siswa berani maju kedepan kelas pada saat guru menunjuknya. Hal ini dapat dilihat dari sebagian besar siswa memilih tidak setuju dari pernyataan angket tersebut. Butir ke-23: Saya tidak akan bersedia mendengarkan keluh kesah teman karena mempunyai banyak masalah. Dari angket dapat diketahui bahwa dari pernyataan saya tidak akan bersedia mendengarkan keluh kesah teman karena mempunyai banyak masalah 16\% siswa menyatakan sangat tidak setuju dan $84 \%$ siswa menyatakan tidak setuju. Dengan demikian dapat disimpulkan tidak benar bahwa siswa tidak akan mendengarkan keluh kesah teman karena mempunyai banyak masalah.

Butir ke-24: Ketika mendapat nilai rendah saya marah dengan diri sendiri. Dari angket dapat diketahui bahwa ada sebanyak 5\% siswa menyatakan sangat tidak setuju, 18\% siswa menyatakan tidak setuju dan $8 \%$ siswa menyatakan setuju. Dengan demikian dapat disimpulkan bahwa ada beberapa siswa yang marah dengan diri sendiri ketika mereka mendapatkan nilai rendah dan sebagian besar siswa tidak merasa marah dan tidak kesal dengan dirinya apabila dirinya mendapatkan nilai rendah. Hal ini menunjukkan bahwa siswa kelas IV SDN Petir 4 mereka bersikap tidak perduli dengan dirinya karena mereka tidak merasa kesal atau mara dengan dirinya ketika mendapatkan nilai rendah. Butir ke-25: Saya tidak merasa cemas jika mendapat nilai ulangan jelek atau buruk. Dari angket dapat diketahui bahwa siswa tidak merasa cemas jika nilai ulangan jelek atau buruk sebanyak $10 \%$ siswa menyatakan tidak setuju dan $15 \%$ siswa menyatakan tidak setuju. Dengan demikian 
dapat disimpulkan bahwa siswa merasa cemas apabila ia mendapatkan nilai ulangan jelek atau buruk. Hal ini dapat ditunjukan pada tabel di atas sebagian besar siswa memilih tidak setuju apabila siswa tidak merasa cemas karena mendapatkan nilai jelek.

Butir ke-26: Saya merasa kesulitan mengajak teman untuk bermain. Dari angket dapat diketahui bahwa siswa merasa kesulitan mengajak teman untuk bermain sebanyak $16 \%$ siswa menyatakan sangat tidak setuju, $72 \%$ siswa menyatakan tidak setuju, dan $12 \%$ siswa tidak setuju. Dengan demikian dapat disimpulkan pendapat siswa bervariasi ada beberapa siswa yang setuju apabila ia merasa kesulitan mengajak teman untuk bermain dikarenakan sikap respon siswa terhadap temannya kurang. Akan tetapi sebagian besar siswa memilih tidak setuju apabila ia merasa kesulitan untuk mengajak temannya bermain.

Butir ke-27: Saya tidak bisa menerima kritik tentang pribadi dari orang lain. Dari angket dapat diketahui bahwa siswa tidak bisa menerima kritik tentang pribadi dari orang lain ada $12 \%$ siswa menyatakan sangat tidak setuju, 56\% siswa tidak setuju, dan $12 \%$ siswa menyatakan tidak setuju. Dengan demikian dapat disimpulkan bahwa ada siswa sebanyak $12 \%$ tidak bisa menerima kritik tentang pribadi dari orang lain karena sikap negatif mereka terhadap orang lain dan sebagian besar siswa tidak setuju dengan penyataan di atas. Butir ke28: Saya tidak dapat menerima pemikiran yang berbeda pendapat. Dari angket dapat diketahui bahwa siswa tidak dapat menerima pemikiran yang berbeda pendapat sebanyak $32 \%$ siswa menyatakan sangat tidak setuju dan $68 \%$ siswa menyatakan tidak setuju. Dengan demikian dapat disimpulkan bahwa sebagian besar siswa memilih tidak setuju apabila siswa tidak dapat menerima pemikiran yang berbeda pendapat hal ini menunjukan bahwa sikap respon siswa positif terhadap temannya. Butir ke-29: Ada teman mendapat nilai bagus maka saya merasa kesal dengannya. Dari angket dapat diketahui ada teman mendapat nilai bagus maka saya merasa kesal dengannya ada sebanyak 52\% siswa menyatakan sangat tidak setuju dan $48 \%$ siswa menyatakan tidak setuju. Dengan demikian siswa berpendapat sangat tidak setuju jika ada teman mendapat nilai bagus maka siswa tersebut merasa kesal dengan temanya. Hal ini ditunjukan pada skor pernyataan di atas.

Butir ke-30: Saya tidak merasa kasihan jika ada teman yang sedang mengalami musibah. Dari angket dapat diketahui bahwa siswa tidak merasa kasihan jika ada teman yang sedang mengalami musibah sebanyak 64\% siswa menyatakan sangat tidak setuju dan $36 \%$ siswa menyatakan tidak setuju. Dengan demikian dapat disimpulkan bahwa siswa masih 
mempunya nilai sikap positif terhadap temannya hal ini dapat dilihat dari hasil persen pada pernyataan tabel di atas. Butir ke-31: Jika mendapat nilai rendah saya tetap berkonsentrasi dalam berfikir. Dari angket dapat diketahui bahwa ada sebanyak $20 \%$ siswa menyatakan sangat setuju, 52\% siswa menyatakan setuju, $13 \%$ siswa menyatakan tidak setuju, dan $6 \%$ siswa menyatakan setuju, dan $4 \%$ siswa menyatakan sangat setuju. Dengan demikian dapat disimpulkan bahwa jawaban siswa sangat bervariasi dalam pernyataan jika mendapat nilai rendah saya tetap berkonsentrasi dalam berfikir akan tetapi tetap sebagian besar siswa memilih tidak setuju karena siswa ketika mendapat nilai rendah siswa tidak berkonsentrasi dalam berfikir. Hal ini dapat ditunjukan pada tabel di atas. Butir ke-32: Saya malas belajar jika tidak ada ulangan IPS. Dari angket dapat diketahui bahwa siswa malas belajar jika tidak ada ulangan IPS itu tidak benar bahwa $24 \%$ siswa menyatakan sangat tidak setuju dan $4 \%$ siswa menyatakan tidak setuju. Dengan demikian dapat disimpulkan bahwa siswa tidak malas belajar jika ada ulangan IPS hal ini menunjukkan bahwa sebagian besar siswa memilih sangat tidak setuju dengan pernyataan di atas.

Butir ke-33: Saya tidak memiliki target dalam pembelajaran IPS. Dari angket dapat diketahui bahwa tidak memiliki target dalam pembelajaran IPS ada sebanyak $28 \%$ siswa menyatakan sangat tidak setuju dan $72 \%$ siswa menyatakan tidak setuju. Dengan demikian dapat disimpulkan bahwa siswa memilki target dalam pembelajaran IPS. Hal ini menunjukkan bahwa sebagian besar siswa memilih tidak setuju jika pernyataan siswa tidak memiliki target dalam pembelajaran IPS. Butir ke-34: Jika nilai ulangan IPS buruk maka saya merobek kertas ulangan. Dari angket dapat diketahui jika nilai ulangan IPS buruk maka saya merobek kertas ulangan, ada sebanyak 52\% siswa menyatakan sangat tidak setuju dan $48 \%$ siswa menyatakan tidak setuju. Dengan demikian dapat disimpulkan bahwa jika nilai ulangan siswa buruk siswa akan merobek ulangan tersebut itu tidak benar. Butir ke-35: Saya tidak memperdulikan teman mengalami kesulitan belajar IPS. Dari angket dapat diketahui bahwa siswa tidak memperdulikan teman mengalami kesulitan dalam pembelajara IPS ada sebanyak $10 \%$ siswa menyatakan sangat tidak setuju dan $60 \%$ siswa menyatakan tidak setuju. Dengan demikian dapat disimpulkan bahwa siswa mempunyai nilai sikap postif terhadap temannya hal ini dapat di tunjukan dengan sebagian besar siswa memilih tidak setuju terhadap pernyataan di atas.

Butir ke-36: Saya hanya diam saja dan tidak pernah memberi pendapat pada saat pembelajaran IPS. Dari angket dapat diketahui bahwa siswa sebanyak $24 \%$ siswa 
menyatakan sangat tidak setuju dan $76 \%$ siswa menyatakan tidak setuju. Dengan demikian dapat disimpulkan bahwa siswa hanya diam saja dan tidak memberi pendapat pada saat pembelajaran IPS itu tidak benar. Hal ini dapat ditunjukan bahwa sebagian besar siswa tidak setuju dengan pernyataan tersebut. Butir ke-37: Saya tidak suka dengan materi pembelajaran IPS. Dari angket dapat diketahui bahwa siswa tidak suka dengan materi pembelajaran IPS ada sebanyak 32\% siswa menyatakan sangat tidak setuju, 68\% siswa menyatakan tidak setuju dan $4 \%$ siswa menyatakan setuju. Dengan demikian dapat disimpulkan bahwa masih ada siswa yang tidak suka dengan pembelajaran IPS walaupun hanya $4 \%$ dan sebagian besar siswa menyukainya hal ini dapat dilihat dari hasil perhitungan tabel di atas. Butir ke-38: Saya tidak pernah mendengarkan guru saat sedang menjelaskan materi IPS di depan kelas. Dari angket dapat diketahui bahwa ada sebanyak 56\% siswa menyatakan sangat tidak setuju dan $44 \%$ siswa menyatakan setuju. Dengan demikian dapat disimpulkan bahwa sebagian besar siswa memilih sangat tidak setuju dari pernyataan saya tidak pernah mendengarkan guru pada saat menjelaskan materi IPS didepan kelas itu tidak benar. Hal ini dapat ditunjukan siswa kelas IV SDN Petir 4 ini memiliki nilai sikap yang positif. Butir ke-39: Saya malas mengikuti kegiatan bakti sosial di sekolah. Dari angket dapat diketahui bahwa siswa malas mengikuti kegiatan bakti sosial di sekolah ada sebanyak $48 \%$ siswa menyatakan sangat tidak setuju dan 52\% siswa menyatakan tidak setuju. Dengan demikian dapat disimpulkan bahwa siswa malas mengikuti kegiatan bakti sosial itu tidak benar. Hal ini menunjukkan bahwa sebagian besar siswa tidak setuju dengan pernyaataan tersebut. Butir ke-40: Jika guru menyuruh untuk mengerjakan soal IPS saya menunggu bantuan dari teman saya. Dari angket dapat diketahui bahwa ada sebanyak 36\% siswa menyatakan sangat tidak setuju dan 64\% siswa menyatakan tidak setuju. Dengan ini dapat disimpulkan bahwa jika guru menyuruh untuk mengerjakan soal IPS saya menunggu jawaban dari teman pernyataan ini tidak benar. Hal ini ditunjukan bahwa sebagian besar siswa tidak setuju terhadap pernyataan tersebut.

\section{SIMPULAN DAN SARAN}

Berdasarkan hasil penelitian yang telah diuraikan dalam bab sebelumnya, dapat penulis simpulkan "Analisis tingkat kecerdasan sosial dalam pembelajaran IPS siswa kelas IV SDN Petir 4 Kota Tangerang" yang bernilai rata-rata 83,12 dengan ini dinyatakan bahwa tingkat kecerdasan sosial siswa dikategorikan tinggi yang artinya, siswa sering mempunyai kesadaran 
situasional, mempunyai kemampuan membawa diri dan mempunyai sifat empati terhadap orang lain. Faktor-faktor yang menyangkut sikap siswa, kemampuan dan kemauan belajar sehingga pada akhirnya proses tersebut mendorong pertumbuhan dan perkembangan kearah suatu tujuan yang dicita-citakan dan diharapkan perubahan tersebut membawa dampak positif. Faktor pendukung tingginya tingkat kecerdasan sosial dalam pembelajaran IPS siswa kelas IV SDN Petir 4 Kota Tangerang karena adanya sikap positif yang diterapkan oleh guru, dorongan dalam diri siswa, dan kepedulian guru terhadap prestasi siswa, guru yang menjadi motivator untuk siswanya. Sehingga guru selalu menanamkan motivasi kepada siswa agar selalu bersikap positif dan juga meningkatkan kecerdasannya. Peran guru di kelas IV SDN Petir 4 ini sudah melaksanakan metode pembelajarannya dengan baik hal ini dapat dilihat dari hasil observarsi yang dilakukan peneliti bahwa guru sudah memberikan metode diskusi dan juga ceramah dalam pembelajaran IPS, guru juga tidak lupa ketika dalam kegiatan pembelajaran maupun diakhir pembelajaran, guru selalu memberikan motivasi kepada siswanya. Guru harus selalu menjadi motivator bagi siswanya.

\section{DAFTAR PUSTAKA}

Aldily, Ridho. (2017). The Power Of Social And Emotional Intelligenc. Yogyakarta: Psikolog Corner.

Moleong, lexy. J. (2016). Metodologi Penelitian Kualitatif. Bandung: PT Remaja Rosdakarya. Sardjijo Ischak. (2017). Pendidikan IPS di SD. Tangerang Banten: Universitas Terbuka.

Sarwono, S. W . (2010). Psikologi Remaja, Edisi Revisi. Jakarta: PT Raja. Grafindo

Soejanto, Laily Tiarani \& F.I. Soekarman. (2015). Tingkat Kecerdasan Sosial Mahasiswa

Fakultas Keguruan dan Ilmu Pendidikan Universitas Kanjuruhan Malang. Jurnal konseling Indonesia. Diakses pada 01 oktober 2015.

Sugiyono. (2016). Metode Penelitian Pendidikan. Bandung: Alfabeta.

Sunar, Prasetyono, Dwi (2010). Tes Iq dan Eq Plus!. Jogjakarta: Buku Biru.

Susanto Ahmad. (2013). Teori Belajar dan Pembelajaran di Sekolah Dasar. Jakarta: Prenadamedia Group.

Undang-undang No. 20 Tahun 2003 tentang Sistem Pendidikan Nasional Online.www.dikti.go.id/files/atur/UU20-2003SiSdiknas.pdf. 